\title{
Review \\ Benefits of Crop Rotation on Climate Resilience and Its Prospects in China
}

\author{
Taize Yu ${ }^{1}$, Leo Mahe ${ }^{2}$, Ying $\mathrm{Li}^{3}{ }^{3}$, Xue Wei ${ }^{4}$, Xiaoshang Deng ${ }^{5}$ (i) and Dan Zhang ${ }^{3,6, *}$ \\ 1 Department of Agricultural Economics, Oklahoma State University, Stillwater, OK 74075, USA; \\ taizeyu@uchicago.edu \\ 2 Shanghai American School, Shanghai 201201, China; leo01pd2026@saschina.org \\ 3 The Nature Conservancy, Beijing 100600, China; ying.li@tnc.org \\ 4 Department of Applied Economics, University of Minnesota, Minneapolis, MN 55455, USA; \\ wei00169@umn.edu \\ 5 Department of Agricultural/Forestry Economics and Management, Northeast Agricultural University, \\ Harbin 150030, China; A08200873@neau.edu.cn \\ 6 Graduate School, Nanjing Agricultural University, Nanjing 210095, China \\ * Correspondence: zhangdan8720@njau.edu.cn
}

Citation: Yu, T.; Mahe, L.; Li, Y.; Wei, X.; Deng, X.; Zhang, D. Benefits of Crop Rotation on Climate Resilience and Its Prospects in China. Agronomy 2022, 12, 436. https://doi.org/ 10.3390 /agronomy12020436

Academic Editor: François Gastal

Received: 26 November 2021

Accepted: 25 January 2022

Published: 10 February 2022

Publisher's Note: MDPI stays neutral with regard to jurisdictional claims in published maps and institutional affiliations.

Copyright: (C) 2022 by the authors. Licensee MDPI, Basel, Switzerland. This article is an open access article distributed under the terms and conditions of the Creative Commons Attribution (CC BY) license (https:// creativecommons.org/licenses/by/ $4.0 /)$.

\begin{abstract}
In the context of climate change, increases in extreme weather have caused a series of problems, severely reduced crop yield, and caused a loss of agricultural cultivation. In addition, because of the high economic benefits, continuous cropping has become more popular but it leads to higher land-use intensity in production systems, aggravating the problems of extreme climate and seriously influencing China's agricultural production and ecological environment. From this, the importance of improvements to cropping systems' resilience to climate change is now much clearer than before. Crop rotation is an important tool for improving the climate resilience of the agricultural production system and effectively solving the shortcomings of the current continuous crop methodology. Crop rotation is indispensable in many national strategies, including food security, ecological environment development, and rural revitalization. This study aimed to promote the improvement of the crop rotation system in China and aimed to play a significant role in guiding China towards the large-scale development of crop rotation. This literature review shows that crop rotation can effectively enhance climate resilience and reduce the fragility of agricultural cropping systems. It then delves into the origin and development of crop rotation, and summarizes the characteristics of crop rotation. In view of the neglect of ecological benefits in China's agricultural development, this article puts forward three suggestions: first, developing crop rotation technology based on local conditions; second, paying attention to the ecological benefits of crop rotation subsidies, followed by implementing appropriate and flexible subsidy policies; and, finally, carrying out rational evaluations and policy adjustment of crop rotation practices.
\end{abstract}

Keywords: extreme weather; fragility; climate resilience; policy suggestion

\section{Introduction}

Agricultural crop cultivation is one of the most sensitive and vulnerable sectors within the context of climate change [1]. Global warming changes the climatic suitability of crop species, and extreme weather, including high temperatures, rainstorms, and floods, results in the loss of crop yields [2]. Moreover, it causes drier and warmer soil, harming beneficial soil microorganisms and animal growth, thus affecting soil health and increasing the severity of plant diseases, pests, weeds, and other issues, which greatly affect crop yield and overall quality [3]. It is common for small-scale farmers to plant the same crop continuously because of the lack of expertise [4]. Planting the same species or closely related species for many years will generate degradation of soil quality and then cause an ecological imbalance, greatly impacting crop yield and quality. It not only leads to the loss 
of soil nutrients and aggravation of pests and diseases, but also further worsens the impact of climate change on agriculture [5].

Crop rotation means planting different crops on the same land during successive growth/seeding cycles [6]. Many researchers have found that crop rotation can effectively improve the climate resilience of crops through the enhancement of water dynamics, soil health, and biological conditions in planting systems. Bowles et al. [7] supported the view that diversified crop rotation can effectively improve soil health and break the cycle of herbivores, weeds, and pathogens, thereby increasing crop yields and bringing high economic benefits. Even under drought conditions, diversified crop rotation can reduce the effects of increased drought intensity and heatwaves by ensuring that the yield of maize and other crops can resist extreme weather. Li et al. [8] pointed out that diversified crop rotation can help improve the stability of the planting system and that, in the presence of extreme weather, a robust agricultural ecosystem can reduce pressure and resist uncontrollable weather and organisms.

Crop rotation has a long history in China. As early as the Warring States Period, a simple crop rotation model was proposed, and the rotation of cereal crops and legumes was found to be beneficial for grain yield [9]. The crop rotation system is highly consistent with China's green development system. It works towards stabilizing farmers' incomes; alleviates the issue of arable land quality degradation, soil fertility debasement, soil pollution, and other ecological crises; and facilitates the achievement of China's carbon-neutral strategic goals [10]. Since 2016, China has carried out trials of crop rotation and fallow systems. The trial area has increased rapidly: from 411,000 hectares in 2016 to 2,667,000 hectares in 2021 (Figure 1). The "Outline of the 14th Five-Year Plan for National Economic and Social Development and Vision 2035 of the People's Republic of China" proposes to continue to expand the trial area and increase capital investment to popularize the crop rotation system [11].

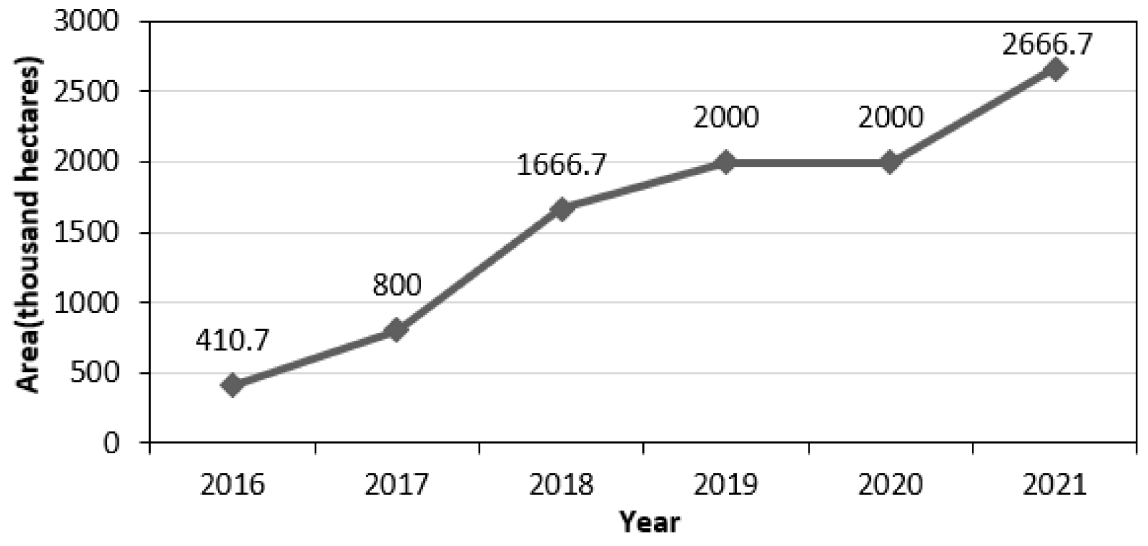

Figure 1. Area of crop rotation and fallow trials in China (Source: Key points of planting industry work in 2016-2021) [12-17].

The article reviews the relevant research progress on crop rotation for improving the climate resilience of agricultural systems to illustrate the role of crop rotation in reducing the fragility of cropping systems. It traces the development history of crop rotation in China to summarize the background and characteristics of crop rotation systems in different periods. Finally, to solve the existing problems in China's crop rotation system, it discusses feasible solutions for regional adjustment of crop rotation technology and improvements in subsidy policies and evaluation mechanism, etc.

\section{Crop Rotation Can Reduce the Fragility of the Planting System}

Extreme weather (typhoons, rainstorms, droughts, high temperature, heat waves, sandstorms, lightning, and other major meteorological disasters) not only seriously damage 
planted or growing crops, but also damage soil health, causing serious pest and disease problems, loss of biodiversity, and low crop yields, while the fragility of agricultural planting systems is gradually exposed [18]. Taking the situation in 2020 as an example, according to statistics, China's crops affected by various meteorological disasters amounted to $19,958,000$ hectares, and the direct economic loss was 57 billion dollars, resulting in farmers receiving lower benefits [19]. Crop rotation can increase farmers' income while ensuring soil health and resisting the effects of climate change. Crop rotation reduces the negative effects of extreme weather on the planting system and reduces the fragility of the agricultural system (Table 1).

Table 1. Benefits of crop rotations.

\begin{tabular}{|c|c|c|}
\hline & Field & Benefit \\
\hline \multirow{3}{*}{ Crop rotation } & Water dynamics $[20,21]$ & $\begin{array}{c}\text { Increased soil water storage and crop water use efficiency [22-25] } \\
\text { Reduced surface water runoff [26-32] }\end{array}$ \\
\hline & Soil health [33-36] & $\begin{array}{c}\text { Improved physical and chemical properties of soil [37-44] } \\
\text { Increases soil enzyme activity, activates nutrients, and improves nutrient } \\
\text { utilization [45-50] } \\
\text { Improves the soil's micro-ecology, reduces the pathogenic bacteria population, and } \\
\text { increases the beneficial bacteria population [51-59] }\end{array}$ \\
\hline & Biology [60-62] & $\begin{array}{c}\text { Reduces the dominance of each weed and controls weeds by enriching the diversity of } \\
\text { weed species [63-70] } \\
\text { Increases the biodiversity of the crop system and disperses the risk of yield } \\
\text { reduction [71-75] }\end{array}$ \\
\hline
\end{tabular}

\subsection{The Role of Crop Rotation in Water Dynamics}

Crop rotation can increase soil water content, reduce water evaporation from the planting system, and reduce surface water runoff, thereby ensuring high crop water use efficiency [20]. This happens as a direct result of water retention and can improve a farm's farming system and ensure sufficient water sources for crops. Because water is stored in crops or soil, the amount of ground water is reduced, which greatly reduces the incidence and severity of flood disasters and enhances the climate resilience of the planting system [21].

\subsubsection{Increased Soil Water Storage and Crop Water Use Efficiency}

In recent years, extreme weather (cold temperature, drought, etc.) has caused significant evaporation of soil water, hindering the process of precipitation. Long-term soil moisture shortages have severely affected soil health and crop yields [22]. To a certain extent, the fragility of the agricultural system has been increased. Fortunately, studies have shown that by properly rotating crops, the resistance of agricultural planting systems to extreme weather can be increased [7]. On one hand, crop rotation can maintain or even increase water storage capacity by improving the ability of the soil to retain water. Wang et al. [23] conducted a maize-potato experiment in Gansu, China, and the results showed that after 6 years of planting, continuous potato cropping would reduce the soil water storage capacity of $0-280 \mathrm{~cm}$ by $186.31 \mathrm{~mm}$, while continuous maize-potato cropping would increase the soil water storage capacity by $11.29 \mathrm{~mm}$. On the other hand, crop rotation can increase the water use efficiency of crops by increasing crop yield, and decreasing soil water evaporation and transpiration of the canopy [24]. The research of Wang et al. [23] showed that, compared with continuous maize cropping, the soil water consumption rate of maize-potato rotation cropping decreased by $16.81-24.83 \%$ and the crop water use efficiency increased by $15.5-23.4 \%$ in 3 years. Han et al. [25] conducted a crop rotation experiment with different combinations of alfalfa after plowing in the Loess Plateau of China and found that after planting rapeseed during the winter, the average grain water use efficiency increased by $44.4 \%$ compared with continuous winter rapeseed 
cropping and by $42.9 \%$ compared with continuous cropping of winter wheat. Crop rotation can greatly increase the soil water content, thus increasing the water use efficiency of crops, promoting the water cycle between the soil and the atmosphere, and giving crops higher resistance to extreme weather.

\subsubsection{Resisting Flood Disasters by Reducing Surface Water Runoff}

An increase in land water evaporation will lead to flooding disasters, and global warming leads to more of this evaporation, which causes increased water content in the atmosphere and higher than average rainfall when it does rain, leading to larger-scale floods, which will seriously affect agricultural production [26]. However, crop rotation has a certain effect on increasing the water infiltration rate and reducing surface water runoff, which will mitigate flood disasters. Baumhard et al. [27] found in an experiment in Texas, United States, that a rotation retaining wheat straw residues increased the penetration of rainwater by more than $25 \mathrm{~mm}$ per hour from a Pullman clay loam, attributing this to the increase in aggregate stability. In addition, the role of crop rotation in reducing surface runoff and alleviating soil erosion has also been confirmed. Carrol et al. [28] carried out a wheat and sunflower rotation experiment in the Central Queensland Plateau, Australia. It showed that if a crop was sown at the right time or when seeding conditions were met, a sunflower-wheat rotation could reduce surface runoff by $13 \%$, increasing transpiration by $17.9 \%$ and decreasing water evaporation, soil loss, and the occurrence of floods, which was clearly shown when compared with continuous sunflower cropping under conditions of less tillage. In general, rotation with cover crops such as legume crops and wheat will not only effectively increase soil water infiltration but also increase soil surface roughness. This is able to reduce surface water runoff while ensuring soil water storage [29]. Crop rotation may not directly affect the occurrence of floods, but it can control the factors that cause floods by affecting soil and hydrological characteristics, and indirectly play a role in drainage. At the on-site level, crop rotation increases soil water content, thereby improving soil stability and reducing soil erosion [30,31]. At the watershed level, crop rotation helps reduce the risk of waterlogging and alleviates flood disasters through reducing both runoff and the flow rate of surface water, and improving drainage capacity [32].

\subsection{The Role of Crop Rotation in Soil Health}

Soil health refers to the sustainability of soil as an important biological ecosystem to maintain the survival of plants, animals, and human beings [33]. Crop rotation effectively improves soil health. First, crop rotation can improve the soil's structure, enhance the soil's physical and chemical properties, boost the soil's erosion resistance, and effectively resist the hazards of extreme weather such as floods and droughts [34]. Furthermore, crop rotation can increase soil enzyme activity, therefore improving soil fertility. This is beneficial for crop growth and increases resistance to extreme weather [35]. Finally, crop rotation can increase the number of beneficial bacteria in the soil and reduce the number of pathogenic microorganisms in the soil, thus reducing the number of crop diseases and pests caused by climate change, therefore ensuring crop growth, improving the quality of crops, and reducing damage to the planting system caused by extreme weather [36].

2.2.1. Improving the Physical and Chemical Properties of Soil, Promoting Root Growth, and Enhancing Crop Resistance

Crop rotation significantly benefits the soil's structure, its physical and chemical properties, and the availability of nitrogen, phosphorus, potassium, and other elements in the soil [37]. Crop stalks, stubble, roots, and fallen leaves are important soil nutrient supplements, while crops like root crops, leafy vegetable crops, and fruit vegetable crops leave few nutrients remaining in the soil. The solution is to introduce crops such as legume crops and gramineous crops to the planting system, making use of biological carbon sequestration to maintain the nitrogen balance of the soil [38]. At the same time, crop rotation can increase the amount of organic soil matter to improve soil fertility and increase the system's 
resistance to extreme weather (including gales and drought). Wright et al. [39] found in a study in Auckland, New Zealand, that after a potato and onion rotation, compared with continuous potato cropping, soil organic matter and soil nitrogen content increased by $12 \%$ and $11 \%$, respectively, and microbial carbon and microbial nitrogen increased by 9.9\% and 7.8\%. Dayegamiye [40] conducted field trials on potato rotations in Quebec, Canada. It was found that after a potato and oats rotation, soil organic matter and nitrogen content increased by $9.5 \%$ and $12.5 \%$, respectively. Chen et al. [41] found from a planting experiment in Yunnan, China, that a flue-cured tobacco-vetch-rice rotation model could effectively improve the nutrients of the original soil, increasing the organic matter by $45 \%$, the alkali-hydroxy nitrogen by $32.5 \%$, the available phosphorus by $227.5 \%$, and the available potassium by $13.3 \%$. In addition, crop rotation can effectively enhance the soil scour's resistance and soil erosion resistance, reduce the severe damage caused by malignant soil erosion due to extreme weather, and reduce the sensitivity of the planting system [42]. Alternate planting of deep-rooted and shallow-rooted plants results in uniform root distribution, good loose soil structure, increased soil porosity and permeability, reduced soil bulk density, improved soil aggregate stability, increased water retention and stability, and increased resistance to soil erosion by extreme weather. A study by Goff [43] in Iowa, USA, found that, compared with continuous cropping, rotating alfalfa with maize could increase the stability of soil aggregates by $35 \%$. Wang et al. [44] conducted a crop rotation experiment in a double-cropping rice area in Jiangxi Province, rotating double-cropped rice with milk vetch, rapeseed, and other crops. The results showed that multiple cropping and rotation in rice fields could effectively reduce microaggregates and form large aggregates. The soil became more stable, which improved the water and soil erosion rate and reduced the likelihood of flooding triggered by extreme weather. Meanwhile, it prevented the loss of pollutants in farmland soil to water bodies, reduced agricultural non-point source pollution, and protected the ecological environment.

\subsubsection{Increasing Soil Enzyme Activity, Activating Nutrients, and Improving} Nutrient Utilization

Soil enzymes are biological catalysts for soil biochemical reactions and participate in a series of biochemical processes in the soil. Soil enzyme activity is usually used to characterize the level of soil fertility. Higher soil enzyme activity can indicate high soil fertility and good soil health [45]. Crop rotation can create a good soil environment, increase soil moisture, and promote the reproduction and growth of microorganisms. Microorganisms act as mediators to catalyze the reaction process of enzymes, thereby increasing enzyme activity, boosting soil fertility, and improving the ability of crops to resist extreme weather [46]. The potato-maize rotation study of Wan et al. [47] found that the soil urease, catalase, and sucrase activities of the sweet potato rotation and the jade yam rotation increased by $5.71 \%, 2.19 \%$, and $4.85 \%$ and $52.07 \%, 32.23 \%$, and $11.62 \%$, respectively, compared with those before sowing, which were much higher than those under potato continuous cropping. In terms of fruit and vegetable crops, Hong et al. [48] found that a lettuce-spinach rotation increased catalase activity by $12.81 \%$ compared with continuous lettuce cropping, and enhanced the abundance and diversity of bacteria in the soil. Xu et al. [49] showed that the soil urease, invertase, catalase, and phosphatase activities increased by $23.4 \%, 5.1 \%, 29.8 \%$, and 12.8 , respectively, after a rotation of apples and onions.

Therefore, crop rotation can effectively improve the soil enzyme activities of cropping systems Soil enzyme activity can characterize potential effective nutrients and the adsorption properties of colloids in the soil. These two characteristics are important indicators of soil quality [50]. Hence, an increase in soil enzyme activity brought about by crop rotation can effectively show the good development of the soil and an improvement in soil fertility. Healthy soil gives strong support to crops against extreme weather. 
2.2.3. Managing Pests and Plant Diseases by Improving the Soil's Micro-Ecology, Reducing the Pathogenic Bacteria Population, and Increasing the Beneficial Bacteria Population

Climate change will cause an imbalance in soil microbial flora and diversity, causing a reduction in the beneficial microbial populations, along with the enrichment of pathogenic microorganisms, which will trigger various soil-borne plant diseases. Launay et al. [51] predicted that by 2100, due to climate change, the risk of wheat leaf rust caused by Puccinia triticina in France is expected to greatly increase. St-Marseille et al. [52] predicted in Quebec, Canada, that the number of generations of Heterodera glycines is expected to increase by 2070. In addition, studies have shown that with an increase in continuous cropping years, the problem of pests and diseases will also become more serious, increasing the damage to the ecological environment [53]. However, crop rotation can reduce the occurrence of soil-borne diseases by increasing the number of soil microbial communities, microbial abundance, the soil bacteria/fungus ratio, and the microbial carbon and nitrogen content. After crop rotation, plant residue enters the soil to provide a carbon source, a nitrogen source, and an energy flow for microbial reproduction. In addition, a decrease in the number of pathogenic fungi reduces their nutritional competition with the bacteria, promoting the bacteria to produce antibiotics and extracellular enzymes and restoring the balance of the soil microecosystem [54]. Meng et al. [55] used PCR-DGGE technology to explore the differences in the soil's fungal community structure between continuous potato cropping and a potatomaize rotation, and found that with the increase in continuous potato cropping years, pathogenic bacteria in the soil, such as Fusarium oxysporum and F. solani increased significantly. Zhao et al. [56] explored the impact of continuous potato cropping and crop rotation on the soil bacterial community through high-throughput sequencing. They concluded that the abundance of beneficial bacteria such as Paenarthrobacter nitroguajacolicus, Acinetobacter calcoaceticus, and Ethizobium etli was higher than that in potato continuous cropping soil. Crop rotation improves the ability of crops to resist soil-borne diseases by increasing the abundance of microorganisms in the soil and the number of microbial communities, and by controlling the number of harmful pathogens, thereby greatly reducing the probability of crops being affected by soil-borne diseases and guaranteeing improvements in crop yield and quality. In Canada, Guo et al. [57] rotated wheat, flax, and other crops with rapeseed, and found that crop rotation could reduce the incidence of rapeseed blackleg by $14-76 \%$ and the severity of the disease by 6-65\%. Adhikari [58], in field trials of crop rotation in Chitwan, Nepal, found that the onset of bacterial wilt was delayed by 1-3 weeks and the severity of bacterial wilt was reduced by $20-26 \%$ after the rotation of tomato and maize, carob, cowpea, or disease-resistant tomato. However, crop rotation cannot control the population of harmful microorganisms when introducing all kinds of crops. Through an experiment at the University of Wisconsin-Madison, Marburger et al. [59] found that the introduction of wheat into a crop rotation increases the presence and population of Fusarium spp.

Therefore, crop rotation can effectively solve the problem of the high incidence of pests and diseases caused by climate change, improve soil health and ecological environment while improving crop quality, reduce the costs of agricultural producers, and promote the green development of agriculture.

\subsection{The Role of Crop Rotation in Biology}

Crop rotation can increase the biodiversity in the planting system [60]. On the one hand, it increases the number of weeds, reducing the dominance of each weed, decreasing the number and density of weeds in the planting system, and resisting the increase in weed populations caused by climate change to guarantee production [61]. On the other hand, the introduction of multiple crops can reduce the exposure of specific crops, share the risk of a particular crop reduction caused by extreme weather, and lower the impact of extreme weather on yield [62]. 
2.3.1. Reduce the Dominance of Each Weed and Control Weeds by Enriching the Diversity of Weed Species

Climate change will cause an increase in weed acreage around the world. Shabani et al. [63] found 32 species of weeds worldwide that are expected to increase by 2050 in European countries, northern Brazil, eastern United States, and southeastern Australia. Wan et al. [64] found eight major weeds in China, and the area of six of them is expected to increase. The growth of weeds often causes many problems. They will compete with crops for resources such as space, light, nutrients, water, etc., resulting in crop failure, an inability to effectively face extreme weather, and declines in yield and quality [65]. Therefore, in production, farmers usually use herbicides for chemical weed control. Most herbicides are not conducive to soil health and cause serious damage to the ecological environment [66]. Crop rotation can affect the weed community and soil seed bank, thus reducing the density of weeds and the number of weed seeds in the soil seed bank [67]. Zohry and Ouda [68] discussed the effect of implementing crop rotation on controlling weeds in Egypt. In an intensive crop rotation, weeds related to wheat, maize, and cotton were reduced by $51 \%, 70 \%$, and $66 \%$. Crop rotation can enrich the diversity of weed species and reduce the dominance of each weed to a certain extent, thus preventing a single weed from becoming a dominant species. The rich species diversity contributes to the good operation of farmland ecosystems. Brankov et al. [69] searched for the best Integrated Weed Management model in Serbia. The results showed that compared with continuous maize cropping, the introduction of winter wheat could effectively reduce weed density and biomass. In a crop rotation system, applying only half of the herbicide had the same effect as the full application rate. If farmers combine crop rotation with the application of isoxaflutole and S-metolachlor, almost all weeds will disappear. Gao et al. [70] studied the diversity of weeds in a long-term rice-rice-milk vetch rotation cropping field in Hunan and found that while the crop rotation reduced the weed density, it also reduced the types of weeds during the growth period of early rice but did not affect the late rice period. The types of weeds ensure the diversity of weeds. By controlling weed density and increasing weed diversity, crop rotation can help farmers better manage weeds, avoid environmental pollution caused by herbicide use, and reduce the fragility of cropping systems.

\subsubsection{Dispersing the Risk of Yield Reduction and Reducing the Fragility of the Planting} System through Diversified Planting

In recent years, the climate has been severely affected by human activities, and extreme weather has repeatedly occurred, creating major problems for the quality and yield of crops. Xie et al. [71] calculated, through a model, that under the worst climate change scenario, China's wheat yield will decline by $9.4 \%$ by 2050. Lin et al. [72] predicted that from 2025 to 2080 , the output of rice, maize, and wheat will reduce by $37 \%$. Crop rotation can reduce the risk of crop losses caused by extreme weather. Crop rotation diversifies the production of agricultural systems. The use of multiple crop rotations can effectively reduce the exposure of specific crops to extreme weather and share the risk of reduced yields caused by extreme weather. Different crops can adapt to different types of extreme weather. Even if a certain type of extreme weather will reduce the yield of a certain crop, the risk of other crops may be lower because there are many types of crops in the system. Degani et al. [73] conducted wheat rotation experiments under different climatic pressures and found that increased crop diversity could ensure yield when external inputs were reduced, and the yield increased by an average of $1 \mathrm{Mg} / \mathrm{ha}$. Crop stress resistance can be improved by crop rotation diversification, thus forming a more resilient system. In addition, because most of the crop rotation combinations are within a year, choosing different time periods to plant suitable crops will not affect the planting area of the main crops. Therefore, in general, under the influence of extreme weather, the diversified planting strategy stabilizes production and reduces the fragility of the planting system.

In addition, climate change will change the phenology, distribution, and abundance of species, making some species extinct, increasing the frequency and intensity of pest 
outbreaks, changing the structure and function of ecosystems, and significantly increasing the fragility of planting systems [74]. The rotation of diversified crops, compared with single crop cultivation, can provide food sources and habitats for different species, facilitating the growth of more animals, plants, and soil microbes, therefore increasing biodiversity. Beillouin et al. [52] collected data on 120 crops in 85 countries around the world for meta-analysis and found that diversification increased crop yields by $14 \%$ and the related biodiversity by $24 \%$. Torralba et al. [75] also used a meta-analysis to summarize 53 studies on agroforestry planting systems in Europe. The results showed that agroforestry planting has a positive effect on biodiversity, and the results were heterogeneous. Therefore, crop rotation technology, unlike traditional agriculture, can effectively resist the adverse impact of climate change on the biodiversity of the agricultural system. Farmland with rich species diversity can better resist pests, promote pollination, reduce the risk of reduced production, and ensure the sustainable development of agricultural systems.

\section{China's History of Crop Rotation}

Crop rotation systems have been practiced in China for a long time. Since the Spring and Autumn Period and the Warring States Period, there have been irregular crop rotations. However, in the process of crop rotation, no other advantageous crop rotation combinations have been explored. The crop rotation system is in a relatively primitive state $[65,66]$. Since the Qin and Han dynasties, China has continuously explored some more profitable crop rotation modes, such as paddy and dry rotations in the southern rice-growing areas, and rotations of beans, cereals, and wheat in the north; at the same time, China has explored some planting techniques that can be combined with crop rotation, such as intercropping, which can greatly increase food production and increase harvests [61-68]. Since the founding of the People's Republic of China, China has gradually strengthened its emphasis on environmental protection, expanded the types of crop rotation, and increased the diversity of crop rotations [69-72]. The development history of crop rotation in China is shown in Table 2.

Table 2. The development of crop rotation in China.

\begin{tabular}{c} 
Time \\
\hline The Spring and Autumn \\
Period and Warring States \\
Period (400 B.C.)
\end{tabular}

The Periods of the Pre-Qin and Han Dynasty (200 B.C.)

The period of the Wei and Jin Dynasties and the South and North Dynasty (200-580 A.D.)

The period of the Sui, Tang, Song, and Yuan Dynasties (580-907 A.D.)

Background and Purpose

It was gradually discovered that crop rotation could reduce the damage to soil fertility caused by continuous cropping, the dominant planting method at the time [76].

Due to the increasing attention paid to soil fertility, farmers actively changed their farming methods to develop crop rotation [77].
Crop Rotation Mode and Characteristics

Random crop rotation was adopted [76]. It was flexible in crop types, rotation sequence, and rotation cycle [77].

Soybean and cereal crop rotations and paddy and dry rotations were initially formed [48].

Intercropping and multiple cropping were also implemented. The cropping system established fixed patterns in different regions [76].

To restore the depressed economy, resist drought, and ensure harvests, people improved farmland water conservancy and farming technology, contributing to development of the crop rotation system [77].

With the emphasis on agriculture, the government set up specialized agencies to assist farmers, promoting the diversification of crop rotation patterns [80]. The demand for crops in south China increased because of population growth, improving the rotation of typical southern crops [81].
Rotations of beans and cereals were widely used [78].

Rotations of food crops and green manure crops received attention [79].

Paddy and dry rotations, and beans and cereal rotations were further developed, and the

double-cropping system of wheat-rice rotation, soybean-rice rotation, and rapeseed-rice rotation were widely promoted [79];

The rotation of grain crops and green manure crops spread to the north [76]. 
Table 2. Cont.

\begin{tabular}{|c|c|c|}
\hline Time & Background and Purpose & Crop Rotation Mode and Characteristics \\
\hline $\begin{array}{l}\text { The period since the Ming and } \\
\text { Qing Dynasties } \\
\text { (1368-1912 A.D.) }\end{array}$ & $\begin{array}{l}\text { To maintain and stabilize the agricultural } \\
\text { economy, people continued the previous crop } \\
\text { rotation system. To improve land utilization to } \\
\text { obtain the maximum economic benefits, } \\
\text { farmers strengthened a combination of crop } \\
\text { rotation and intercropping [81]. }\end{array}$ & $\begin{array}{l}\text { In the south, the rice-based crop rotation was } \\
\text { mature, while in the north, the cotton-grain } \\
\text { rotation was dominant [76]; } \\
\text { Rotation with intercropping was more widely } \\
\text { used, such as interplanting winter wheat with } \\
\text { maize in the 2-yearly triple cropping zone [81]. }\end{array}$ \\
\hline $\begin{array}{c}\text { Since the establishment of the } \\
\text { People's Republic of } \\
\text { China (1949) }\end{array}$ & $\begin{array}{l}\text { To solve the problem of food shortages due to } \\
\text { the large population base and rapid growth } \\
\text { [82], the country actively promoted the } \\
\text { intensive and high-yield crop rotation method } \\
\text { to improve grain yield. }\end{array}$ & $\begin{array}{l}\text { The area of double-cropping and } \\
\text { triple-cropping per year expanded. Fruit and } \\
\text { vegetable crops were added to the rotation [83]. } \\
\text { The cropping system was developed to } \\
\text { improve the multi-cropping index and } \\
\text { crop diversification. }\end{array}$ \\
\hline
\end{tabular}

China has a long rotation cropping history. Various cropping rotation systems have been hugely important, and a large amount of planting experience has been accumulated in production. However, throughout the historical development of crop rotation in China, farmers have mainly focused on economic benefits, ignoring the ecological benefits that crop rotation itself can bring [84]. With the emergence of climate problems in recent years, climate disasters have occurred more frequently, massively impacting the agricultural development of China. Crop rotation is an effective way to improve the climate resilience of the cropping system, and it is therefore vital to explore crop rotation technology with higher climate resilience in mind for future development.

\section{Outlook of Crop Rotation in China}

In response to the aforementioned problems, China should improve crop rotation technology and further optimize the crop rotation system. China must recognize the ecological challenges in different regions and strengthen the implementation of beneficial techniques (e.g., conservation tillage, cover crops, water-saving irrigation, etc.) to obtain ecological benefits, including enhanced climate resilience. The government should also strengthen publicity on and the promotion of crop rotation to cope with climate change, accurately implement crop rotation subsidy policies, and carry out reasonable evaluations or policy adjustments of crop rotation on time, so as to improve China's crop rotation system and contribute to the development of China's rural revitalization.

\subsection{Optimize Crop Rotation Systems in Response to Climate Change and Develop Supporting Technologies in Accordance with Local Conditions}

Climate change puts forward more requirements for the implementation of crop rotation technology. Therefore, identifying regional ecological challenges, conducting rational crop rotations, and strengthening the implementation of supporting technologies are key to proper execution.

China has a large land area, with significant differences in climate and soil among regions, leading to dramatic differences in ecological challenges. Agro-ecological zones are regional areas divided according to soil, terrain, and climate characteristics, and each region has similar constraints and development potential in land use [85]. It is necessary to improve the planting structure and develop suitable crop rotation techniques according to the different agro-ecological zones. China's agro-ecological zones are divided into 10 regions: the middle-lower reaches of Yangtze, Jiangnan, South, Sichuan, Southwest, Qinghai-Tibet Plateau, Northeast, Huang-Huai-Hai, Northwest, and North Platea (Appendix A Figure A1) [86]. It is essential to determine a win-win economic and environmental crop rotation method according to the different natural and socio-economic conditions in each agro-ecological zone. The following section will describe the climatic and environmental characteristics of the major productive zones, including Northwest, 
Huang-Huai-Hai, Northeast, the middle-lower reaches of the Yangtze River, South, and Southwest; demonstrate the challenges they face and explain what crop rotation methods they can use and how rotations can help solve challenges.

Most of the irrigated areas in northwest China have a temperate continental climate and alpine climate, with severely cold and dry winters, high temperatures in summer, scanty precipitation, and large daily and annual temperature differences. This area is the most sensitive zone in response to climate change, and the overall warming and drying trend is obvious. Drought is a frequent climate problem in this region [87]. Therefore, it is recommended to add potato, maize, cotton, and other crops to the rotation process because these crops are drought-tolerant, require less water, play a role in preserving water, and can make full use of favorable conditions, including sufficient sunlight and heat, to increase crop yields [88]. In addition, supporting measures for conservation tillage can be adopted. Conservation tillage, which involves reducing tillage and using crop residues to cover the land, helps the soil retain nutrients and moisture, reduces the damage caused by drought to crops, and enhances the resistance of cropping systems to extreme weather [89]. Such measures can effectively solve the climate problems faced by the Northwest. The application of conservation tillage in the maize-wheat-soybean rotation system in the west of the Loess Plateau showed that maize yield increased by $9.97 \%$ under the conditions of traditional tillage + straw mulching, and the average water storage increased by $7.4 \mathrm{~mm}$ under the conditions of no-tillage + straw mulching, compared with conventional tillage [90]. Thus, conservation tillage can significantly increase the benefits of crop rotation, allowing the soil to retain water, reduce erosion, and withstand dry weather in the Northwest.

The Huang-Huai-Hai Plain of northern China has a temperate monsoon climate. In recent years, precipitation has decreased significantly, the temperature has increased vastly, and extreme weather events have occurred frequently. There is a serious warming trend and a clear drying trend, resulting in the low water use efficiency of crops [91]. Therefore, the main challenges facing this area are drought and water shortages, meaning it is particularly important to save water resources in crop planting for this region. During the process, the planting area of crops with high water consumption should be limited, and drought-resistant varieties should be cultivated and introduced. The addition of maize and potato to the rotation with wheat can effectively improve water use efficiency [92], which would not only adapt to the trend of decreasing precipitation but would also maintain water and resist drought in this environment. At the same time, the planting structure should be adjusted in appropriate areas. The joint development of the planting industry, the fruit growing industry, and the animal breeding industry should be adopted to ensure economic benefits. Moreover, in the selection of supporting technologies for crop rotation, attention should be paid to water-saving concepts, including dryland water collection and water-saving tillage. Agricultural technologies, including drip irrigation, spray pipes, and pipeline irrigation, should be promoted so farmers can effectively conserve water, reducing evaporation in the farming process and resisting the arid climate in this environment [93]. After adopting water-saving irrigation in the winter wheat and summer maize rotation regions in north China, the annual yield and annual water use efficiency increased by $5.19 \%$ and $18.97 \%$ compared with adopting heavy irrigation [94]. Therefore, considering the rotation-based benefits, water-saving irrigation can increase crop yield, increase water use efficiency, improve the effectiveness of rainfall, and reduce dependence on groundwater.

Northeast China has a temperate monsoon climate with four distinct seasons, being warm and rainy in summer, and cold and dry in winter. However, the annual mean surface temperature has increased significantly in recent years, the decadal change in precipitation's has been obvious, sunshine hours have declined significantly, the number of high-temperature days has increased slightly, and the frequency of low-temperature days or cold waves has fallen greatly, the snow accumulation period has been shortened, and the maximum depth of snow has been reduced. The trend of warming and drying is obvious, with frequent occurrence of sandstorms, droughts, floods, salinization, and other 
problems [95]. Therefore, rice planting in crop rotations should be promoted for northeast China, making full use of the increased temperature and increased heat resources, and increasing food output to avoid the adverse effects of rising temperature on crop growth as far as possible, thus adapting to the trend of climate warming. Furthermore, due to the abundant heat in summer, it would be a good choice to select mid-to-late-maturing maize varieties and the drought-tolerant, waterlogged, and saline-alkali-tolerant maize varieties [96]. In addition to climate problems, the soil in northeast China also has serious issues. The black soil in northeast China is recognized as the most fertile land in the world. However, because of extreme weather such as floods and strong winds, the precious topsoil of farmland has been greatly diminishing [97]. Therefore, conservation tillage with straw can be applied to farmland in northeast China. Furthermore, it can effectively protect soil moisture and nutrients, along with reducing greenhouse gas emissions and slowing down climate change. According to the findings of the DNDC model simulation [98], conservation tillage with straw can effectively protect soil moisture and nutrients, reduce greenhouse gas emissions, and slow down climate change. Therefore, it can be applied to farmland in northeast China.

Unlike the dry weather in the north, the middle and lower reaches of the Yangtze River, South China, and southwest China mostly have subtropical monsoon and tropical monsoon climates. It is hot and rainy in summer, and mild and rainy in winter. It is humid all year round and has four distinct seasons. In recent years, rainfall has increased gradually, the temperature has increased significantly, and wind speed and cloud cover have decreased, the number of high-temperature and haze days has increased. Extreme climate events have shown a rising trend, with frequent impacts of typhoons, severe storm surges, and frequent flooding, resulting in a decrease in biodiversity, an increase in the growth of weeds, and greatly increased fragility [99]. To solve this problem, we should increase the planting of tropical crops (e.g., rubber) in crop rotations to make use of the rich heat resources, increasing the absorption of water and adapting to the warmer and wetter climate. We should cultivate and introduce rice, sweet potato, and other varieties that are resistant to disease, pests and waterlogging to reduce the negative impacts, which will help resist flood disasters and stabilize crop yields [92]. Adding cover crops in the rotation system is also a beneficial practice. After planting cover crops in winter in rice-growing areas in south China, Chinese milkvetch increased soil microbial carbon content by $13.97 \%$, soil microbial nitrogen by $152.46 \%$, dry matter yield by $14.11 \%$, and rice yield by $10.87 \%$ [100]. Cover crops can improve and stabilize the soil's organic matter content, reduce crop nutrient losses, lower fertilizer applications, enhance soil stability, alleviate soil erosion, and fight against extreme weather such as floods and freezing [101], which can effectively solve the challenges in the middle and lower reaches of the Yangtze River, South China, and southwest China.

\subsection{Pay Attention to Subsidies for the Ecological Benefits of Crop Rotation, Implement Subsidy Policies Differently, and Improve Green Finance}

There are some issues with the current crop rotation subsidy policy in China. First, the crop rotation subsidies mainly focus on spring and summer crops and ignore winter cover crops [102], leading to the low enthusiasm of farmers about planting cover crops in autumn and keeping farmers away from gaining the full advantage of crop rotation stratagems during the winter. Second, the subsidy policy for crop rotation is single and uniform. The subsidy standards for a province or a city are the same, not considering the weather, economic, and/or environmental conditions [103]. It lacks flexibility without validity in the market mechanism. Third, the subsidy issuance procedure is complicated, and it is prone to inefficiency, corruption, embezzlement, and other problems [103]. These problems limit the incentive function of the subsidy policy and are not conducive to the development of crop rotation systems in different regions.

To solve these issues, subsidies for the ecological benefits of crop rotation should be promoted, including planting subsidies for winter cover crops, which can cover the soil 
surface during the high winds of north China's winter to resist wind erosion and bring additional economic benefits to farmers [102]. Moreover, a flexible subsidy system is an important guarantee for crop rotation development and a policy tool in response to extreme weather. The government should strengthen the degree of refinement for subsidy policies, carry out differentiated and precise subsidies, and formulate different subsidy standards for different regions and crop types to support crop rotation technologies and prevent the problem of oversubsidization and undersubsidization [103]. Moreover, the government should simplify the granting procedures for subsidies and connect the departments of granting subsidies directly to farmers as much as possible. The government should diversify the subsidy method, improve the subsidy evaluation system, and accurately analyze farmers' needs from unique levels and angles. For example, in the United States, direct payment subsidies are very rare, whereas crop insurance plans, income guarantee subsidies, and price support are extremely widespread subsidy methods, which effectively reduce farmers' risks by guaranteeing their income and providing funds [104]. Insurance companies, trust companies, and government agencies should all become involved in subsidies for crop production. The government could more accurately and scientifically evaluate the farmers' plans and give subsidies according to market feedback, reducing the risks of rotation techniques, and therefore preventing farmers' losses from the short-term use of crop rotation measures. This will increase their confidence, effectively promote crop rotation technology, and reduce the fragility of the planting system in the long run. In addition to monetary subsidies, the government can also provide non-monetary grants. They can purchase high-quality seeds for specific crops and distribute them to farmers free of charge. In addition, the government can provide technical assistance for farmers. For example, in the US's 2018 Farm Bill, the Environmental Quality Incentives Program introduced 5- to 10-year incentive contracts allowing farmers who adopted climate-smart conservation practices, including crop rotation, to receive technical assistance [105]. This increased the enthusiasm of pioneers to adopt new crop varieties and technologies, and promoted the development of a planned sequence of specific crops. Finally, for crop rotation technology innovations and applications, governments should adjust subsidies to increase the intensity of subsidies for emerging technologies, shifting support to effective measures more directly targeted towards climate resilience [106]. From this, they should provide more funding for productivity research and development and subsidize the cost of applying these technologies.

\subsection{Establish a Reasonable Assessment of the Application of Crop Rotation Technology and Make} Policy Adjustments in Time

Crop rotation, as a technology that can increase the climate resilience of cropping systems, needs to be implemented over a long period of time to be effective. The government should conduct regular inspections and evaluations. In many cases, due to the lack of experience, there are loopholes in the implementation of crop rotation technology, including an inability to select a suitable crop rotation and the lack of use of supporting technologies that can cooperate with crop rotation [107]. Therefore, regular inspection and evaluation can effectively find out previous mistakes, adjust in time, and maximize crop rotation efficiency. One of the most important things is to develop a detailed and accurate standard assessment system for the acceptance of grassroots organizations. The United States and Canada established environmental benefit assessment systems based on soil census data, cultivated land geographic information data, and social and economic data, and focused on adjusting crop rotation methods according to global grain yield and market conditions, achieving good results [108]. Soon, China should also focus on improving its soil and geographic information databases, along with formulating accurate indicators, accelerating monitoring methods (e.g., remote sensing technology), and cooperating with third-party institutions to regularly evaluate crop rotations and to make relevant and timely adjustments. This will make the crop rotation system move towards a healthy development path. In addition, evaluations should not only focus on economic benefits but also give 
importance to ecological benefits. Sustainability assessment mechanisms need to be based on complete data on soil health, systemic biodiversity, etc. to track the performance of modified farming practices during the climate change adaptation program in the area [106]. The establishment of complete, consistent, comparable, and transparent assessment criteria can accurately measure the outcome of local actions and facilitate learning and communication among different regions to update to newer action plans, effectively aiding to reduce the cropping system's fragility.

\subsection{Improve the Ability of Farmers to Resist Climate Risks and Strengthen the Training and Promotion of Climate Change Adaptation Technology}

Farmers are the main implementers of agricultural production activities. Most farmers in China are not well educated. They lack agricultural knowledge and technology, along with environmental protection consciousness, and tend not to take the initiative to adopt the rotation planting techniques of extreme weather, resulting in severe yield losses from extreme weather [109]. Strengthening the promotion of environmentally friendly agricultural technologies and climate change education will improve farmers' ideological level and effectively publicize crop rotation policies and methods, therefore improving climate change knowledge and the green skills required by farmers to utilize crop rotation. China can learn from the practices of other countries and carry out publicity and promotion in several ways [110]. First, seminars should be held regularly in villages, towns, and counties. Participants can include farmers, employees of agricultural enterprises, university professors, and government staff, etc., providing a good platform for them to strengthen the connection between theory and practice. Second, the government should carry out similar training to explain to farmers the local rotation measures and policies for sustainable agricultural development, helping them to adjust their farming and tackle the impact of the extreme weather in a scientific and effective way. During the training period, government workers also can learn about the ideas and needs of agricultural workers to provide good advice for future work [108]. Third, we should encourage the development of non-governmental voluntary organizations, which can effectively assist the work of the government and be closer to farmers, contributing to training and education. Through effective training and promotion, farmers can be exposed to advanced crop rotation techniques, and their understanding of relevant policies can be promoted effectively [110], which will help improve climate resilience and reduce the fragility of cropping systems.

\section{Conclusions}

In summary, crop rotation can effectively reduce the fragility of cropping systems. Concerning water, crop rotation can improve soil water content and crop water efficiency by adding water-retaining crops into the cropping system. In terms of soil, crop rotation can effectively improve the soil's physical and chemical properties, increasing soil enzyme activity, boosting soil fertility and stability, and enhancing the ability of the planting system to resist extreme weather. In terms of biology, crop rotation can not only improve the soil's microbial ecology and increase the content of beneficial bacteria in the soil, reducing insect pests and plant diseases in the planting system, but also can increase the biodiversity of the ecological system, reducing the presence of a single weed to reduce the number of weeds, diminishing the damage of weeds withing planting system, and safeguarding the ecological balance of nature. Moreover, the climate resilience of cropping systems is greatly enhanced, as crop rotation reduces crop exposure and the risk of yield reductions. As climate issues become more prominent, China should develop supporting technologies for crop rotation in the future, formulate policies related to crop rotation according to local conditions, refine subsidies, improve farmers' awareness of crop rotation through training, and strengthen the supervision of crop rotation technology. Crop rotation can have better application and development prospects in the future to effectively guarantee the climate resilience of the cropping system. 
Author Contributions: Conceptualization, T.Y. and D.Z.; writing-original draft preparation, T.Y. and X.W.; writing-review and editing, L.M., X.D., Y.L. and D.Z. All authors have read and agreed to the published version of the manuscript.

Funding: This research was funded by TNC-Syngenta "China Arid and Semi-arid Region Sustainable Agriculture Demonstration Project" (grant number P118870).

Institutional Review Board Statement: Not applicable.

Informed Consent Statement: Not applicable.

Acknowledgments: Authors would like to thank Yinlong Xu, researcher of Institute of Agricultural Environment and Sustainable Development, Chinese Academy of Agricultural Sciences, for accurate revision of the manuscript.

Conflicts of Interest: The authors declare no conflict of interest.

\section{Appendix A}

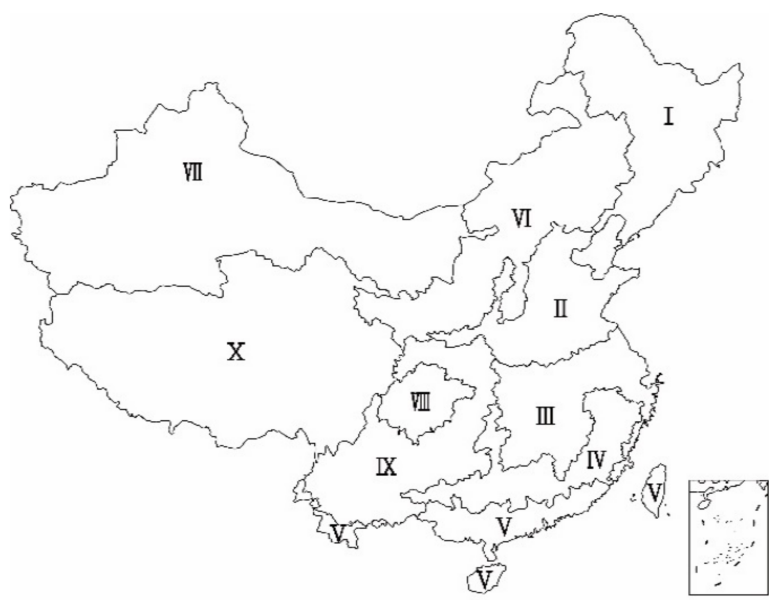
I. Northeast
II. Huang-Huai-Hai
III. Middle-lower reaches of Yangtze
IV. Jiangnan
V. South
VI. North plateau
VII. Northwest
VIII. Sichuan
IX . Southwest
X. Qinghai-Tibet Plateau

Figure A1. Agro-ecological zones of China [86].

\section{References}

1. Kurukulasuriya, P.; Rosenthal, S. Climate Change and Agriculture: A Review of Impacts and Adaptations; World Bank: Washington, DC, USA, 2013.

2. Stott, P. How climate change affects extreme weather events. Science 2016, 352, 1517-1518. [CrossRef] [PubMed]

3. Zhang, X.; Pan, Z.; Zhou, X.; Ni, W. Autotoxicity and continuous cropping obstacles: A review. Chin. J. Soil Sci. 2007, 4, 781-784.

4. Chen, X.; Jiang, L.; Zhang, G.; Meng, L.; Pan, Z.; Lun, F.; An, P. Green-depressing cropping system: A referential land use practice for fallow to ensure a harmonious human-land relationship in the farming-pastoral ecotone of northern China. Land Use Policy 2021, 100, 104917. [CrossRef]

5. Delang, C.O. The consenquences of soil degradation in China: A review. Geoscape 2018, 12, 92-103. [CrossRef]

6. Arriaga, F.J.; Guzman, J.; Lowery, B. Conventional agricultural production systems and soil functions. Soil Health Intensif. Agroecosytems 2017, 1, 109-125. 
7. Bowles, T.M.; Mooshammer, M.; Socolar, Y.; Calderón, F.; Cavigelli, M.A.; Culman, S.W.; Deen, W.; Drury, C.F.; Garcia, A.G.; Gaudin, A.C.; et al. Long-term evidence shows that crop-rotation diversification increases agricultural resilience to adverse growing conditions in North America. One Earth 2020, 2, 284-293. [CrossRef]

8. Li, J.; Huang, L.; Zhang, J.; Coulter, J.A.; Li, L.; Gan, Y. Diversifying crop rotation improves system robustness. Agron. Sustain. Dev. 2019, 39, 1-13. [CrossRef]

9. Huang, G.Q.; Zhao, Q.G. A discussion on land fallow rotation problem. Ecol. Environ. Sci. 2017, 26, 357-362.

10. Wu, P.; Wand, Y.G. Establishing system of ecological compensation for farmland rotation. Theory Reform 2017, 4, $20-27$.

11. The People's Government of Fujian Province. Available online: https://www.fujian.gov.cn/english/news/202108/t20210809_56 65713.htm (accessed on 28 August 2021).

12. Ministry of Agriculture and Rural Affairs of the People's Republic of China. Key Points of Planting Industry Work in 2016. Available online: http:/ / www.zzys.moa.gov.cn/tzgg/201602/t20160215_6310621.htm (accessed on 25 November 2021).

13. Ministry of Agriculture and Rural Affairs of the People's Republic of China. Key Points of Planting Industry Work in 2017 Available online: http://www.cnafun.moa.gov.cn/zx/zyzc/201703/t20170315_5521732.html (accessed on 25 November 2021).

14. Ministry of Agriculture and Rural Affairs of the People's Republic of China. Key Points of Planting Industry Work in 2018. Available online: http:/ / www.moa.gov.cn/ztzl/ncgzhy2017/zxdt/201802/t20180203_6136400.htm (accessed on 25 November 2021).

15. Ministry of Agriculture and Rural Affairs of the People's Republic of China. Key Points of Planting Industry Work in 2019. Available online: http://www.moa.gov.cn/ztzl/2019gzzd/sjgzyd/201903/t20190315_6176675.htm (accessed on 25 November 2021).

16. Ministry of Agriculture and Rural Affairs of the People's Republic of China. Key Agricultural and Rural Work in 2020. Available online: http:/ / www.moa.gov.cn/nybgb/2020/202002/202004/t20200414_6341533.htm (accessed on 25 November 2021).

17. Ministry of Agriculture and Rural Affairs of the People's Republic of China. Key Agricultural and Rural Work in 2021. Available online: http:/ / www.moa.gov.cn/ztzl/2021gzzd/gzyd/202103/t20210301_6362430.htm (accessed on 25 November 2021).

18. Rosenzweig, C.; Iglesias, A.; Yang, X.B.; Epstein, P.R.; Chivian, E. Climate Change and Extreme Weather Events; Implications for Food Production, Plant Diseases, and Pests. Glob. Change Hum. Health 2001, 2, 90-104. [CrossRef]

19. China News. Available online: http:/ / www.chinanews.com/gn/2021/01-02/9377255.shtml (accessed on 18 July 2021).

20. Bordovsky, J.P.; Lyle, W.M.; Keeling, J.W. Crop rotation and tillage effects on soil water and cotton yield. Agron. J. 1994, 86, 1-6. [CrossRef]

21. Pala, M.; Ryan, J.; Zhang, H.; Singh, M.; Harris, H.C. Water-use efficiency of wheat-based rotation systems in a Mediterranean environment. Agric. Water Manag. 2007, 93, 136-144. [CrossRef]

22. Rossato, L.; Alvalá, R.C.; Marengo, J.A.; Zeri, M.; Cunha, A.P.; Pires, L.; Barbosa, H.A. Impact of soil moisture on crop yields over Brazilian semiarid. Front. Environ. Sci. 2017, 5, 73. [CrossRef]

23. Wang, H.; Zhang, X.; Yu, X.; Hou, H.; Fang, Y.; Ma, Y.; Zhang, G. Maize-potato rotation maintains soil water balance and improves productivity. Agron. J. 2021, 113, 645-656. [CrossRef]

24. Hatfield, J.L.; Dold, C. Water-use efficiency: Advances and challenges in a changing climate. Front. Plant Sci. 2019, 10, 103. [CrossRef] [PubMed]

25. Han, L.; Ding, J.; Han, Q.; Ding, R.; Nie, J.; Jia, Z.; Li, W. Effects of alfalfa-grain (oil) crop plowing rotation on soil moisture and crop yield in Loess Plateau. Trans. Chin. Soc. Agric. Eng. 2021, 28, 129-137.

26. Trenberth, K.E. The impact of climate change and variability on heavy precipitation, floods, and droughts. Encycl. Hydrol. Sci. 2005, 17, 1-11.

27. Baumhardt, R.L.; Johnson, G.L.; Schwartz, R.C. Residue and long-term tillage and crop rotation effects on simulated rain infiltration and sediment transport. Soil Sci. Soc. Am. J. 2012, 76, 1370-1378. [CrossRef]

28. Carroll, C.; Halpin, M.; Burger, P.; Bell, K.; Sallaway, M.M.; Yule, D.F. The effect of crop type, crop rotation, and tillage practice on runoff and soil loss on a Vertisol in central Queensland. Soil Res. 1997, 35, 925-940. [CrossRef]

29. Laloy, E.; Bielders, C.L. Effect of intercropping period management on runoff and erosion in a maize cropping system. J. Environ. Qual. 2010, 39, 1001-1008. [CrossRef]

30. Cebecauer, T.; Hofierka, J. The consequences of land-cover changes on soil erosion distribution in Slovakia. Geomorphology 2008, 98, 187-198. [CrossRef]

31. Adiku, S.G.K.; Narh, S.; Jones, J.W.; Laryea, K.B.; Dowuona, G.N. Short-term effects of crop rotation, residue management, and soil water on carbon mineralization in a tropical cropping system. Plant Soil 2008, 311, 29-38. [CrossRef]

32. Cornelis, W.; Waweru, G.; Araya, T. Building resilience against drought and floods: The soil-water management perspective. In Sustainable Agriculture Reviews 29; Springer: Cham, Switzerland, 2019; pp. 125-142.

33. Kibblewhite, M.G.; Ritz, K.; Swift, M.J. Soil health in agricultural systems. Philos. Trans. R. Soc. B Biol. Sci. 2008, 363, 685-701. [CrossRef] [PubMed]

34. Chan, K.Y.; Heenan, D.P. The influence of crop rotation on soil structure and soil physical properties under conventional tillage. Soil Tillage Res. 1996, 37, 113-125. [CrossRef]

35. McDaniel, M.D.; Grandy, A.S.; Tiemann, L.K.; Weintraub, M.N. Crop rotation complexity regulates the decomposition of high and low quality residues. Soil Biol. Biochem. 2014, 78, 243-254. [CrossRef]

36. Yin, C.; Jones, K.L.; Peterson, D.E.; Garrett, K.A.; Hulbert, S.H.; Paulitz, T.C. Members of soil bacterial communities sensitive to tillage and crop rotation. Soil Biol. Biochem. 2010, 42, 2111-2118. [CrossRef] 
37. Sarwar, G.; Schmeisky, H.; Hussain, N.; Muhammad, S.; Ibrahim, M.; Safdar, E. Improvement of soil physical and chemical properties with compost application in rice-wheat cropping system. Pak. J. Bot. 2008, 40, 275-282.

38. Repullo-Ruibérriz de Torres, M.A.; Moreno-García, M.; Ordóñez-Fernández, R.; Rodríguez-Lizana, A.; Cárceles Rodríguez, B.; García-Tejero, I.F.; Zuazo, V.H.; Carbonell-Bojollo, R.M. Cover Crop Contributions to Improve the Soil Nitrogen and Carbon Sequestration in Almond Orchards (SW Spain). Agronomy 2021, 11, 387. [CrossRef]

39. Wright, P.J.; Falloon, R.E.; Hedderley, D. Different vegetable crop rotations affect soil microbial communities and soilborne diseases of potato and onion: Literature review and a long-term field evaluation. N. Z. J. Crop. Hortic. Sci. 2015, $43,85-110$. [CrossRef]

40. N’Dayegamiye, A.; Nyiraneza, J.; Grenier, M.; Bipfubusa, M.; Drapeau, A. The benefits of crop rotation including cereals and green manures on potato yield and nitrogen nutrition and soil properties. Adv. Crop Sci. Technol. 2017, 5, 279.

41. Chen, D.; Chen, X.; Liang, Y.; Huo, X.; Zhang, C.; Duan, Y.; Yang, Y.; Yuan, L. Influence of crop rotation on soil nutrients, microbial activities and bacterial community structures. Acta Prataculturae Sinica 2015, 24, 56-65.

42. Troeh, F.R.; Thompson, L.M. Soils and Soil Fertility, 6th ed.; Blackwell: New York, NY, USA, 2005; pp. 1-10.

43. Goff, B. Putting Some Pop Back in Your Crop: Alfalfa in Crop Rotations. Available online: https://uknowledge.uky.edu/cgi/ viewcontent.cgi? article $=1006 \&$ context $=k y \_$grazing (accessed on 24 August 2021).

44. Wang, Z.Q.; Liu, Y.; Yang, W.T.; Zhao, Q.; Muhammad, A.; Wang, H.; Huang, G.Q.; Zhao, Q.G. Effects of rotation and fallow in paddy field on distribution and stability of soil aggregates. Acta Pedologica Sinica 2018, 55, 1143-1155.

45. Zhang, C.; Shi, S.; Kang, W.; Zhao, S.; Huang, Z.; Li, Y. Characters of soil enzyme activity and its relationship with chemical properties under different rotation pattern. Chin. J. Grassl. 2020, 42, 92-102.

46. Guo, J.; Lin, H.; Jiang, S. Enzymic activity of alkaline meadow soil with different grassland vegetations. Chin. J. Appl. Ecol. 1997, $8,412-416$.

47. Wan, N.; Zheng, S.; Zhou, S.; Zhang, Q.; Peng, B.; Yuan, J. Analysis of potato-maize rotation on rhizosphere soil nutrient and enzyme activity for potato. J. Zhejiang Univ. (Agric. Life Sci.) 2016, 42, 74-80.

48. Hong, J.; Kang, J.; Liu, Y.Q.; Gao, X.Z.; Yi, X.X. Effects of Continuous Cropping of Lettuce and Rotation of Lettuce-Spinach on Soil Bacterial Community Structure. Biotechnol. Bull. 2019, 35, 17.

49. Xu, S.; Liu, Y.; Xia, M.; Wang, Y.; Chen, X.; Shen, X.; Yin, C.; Mao, Z. Dazomet fumigation and short-time Allium fistulosum rotation can significantly reduce the apple replant disease. Acta Hortic. Sinica 2018, 45, 11-20.

50. Qiu, L.; Liu, J.; Wang, Y.Q.; Sun, H.M.; He, W.X. Research on relationship between soil enzyme activities and soil fertility. Plant Nutr. Fertil. Sci. 2004, 3, 11-16.

51. Launay, M.; Zurfluh, O.; Huard, F.; Buis, S.; Bourgeois, G.; Caubel, J.; Huber, L.; Bancal, M.O. Robustness of crop disease response to climate change signal under modeling uncertainties. Agric. Syst. 2020, 178, 102733. [CrossRef]

52. St-Marseille, A.; Bourgeois, G.; Brodeur, J.; Mimee, B. Simulating the impacts of climate change on soybean cyst nematode and the distribution of soybean. Agric. For. Meteorol. 2019, 264, 178-187. [CrossRef]

53. Jiang, X. Analysis of cotton and agriculture continuous cropping behavior. Chin. J. Agric. Resour. Reg. Plan. 2009, 30, 47-50.

54. Perez, C.; Dill-Macky, R.; Kinkel, L.L. Management of soil microbial communities to enhance populations of Fusarium graminearum-antagonists in soil. Plant Soil 2008, 302, 53-69. [CrossRef]

55. Meng, P.P.; Liu, X.; Qiu, H.Z.; Zhang, W.M.; Zhang, C.H.; Wang, D.; Zhang, J.L.; Shen, Q.R. Fungal population structure and its biological effect in rhizosphere soil of continuously cropped potato. J. Appl. Ecol. 2012, 23, 3079-3086.

56. Zhao, J.; Zhang, D.; Yang, Y.; Pan, Y.; Zhao, D.; Zhu, J.; Zhang, L.; Yang, Z. Dissecting the effect of continuous cropping of potato on soil bacterial communities as revealed by high-throughput sequencing. PLoS ONE 2020, 15, e0233356. [CrossRef]

57. Guo, X.W.; Fernando, W.G.D.; Entz, M. Effects of crop rotation and tillage on blackleg disease of canola. Can. J. Plant Pathol. 2005, 27, 53-57. [CrossRef]

58. Adhikari, T.; Basnyat, R. Effect of crop rotation and cultivar resistance on bacterial wilt of tomato in Nepal. Can. J. Plant Pathol. 1998, 20, 283-287. [CrossRef]

59. Marburger, D.A.; Venkateshwaran, M.; Conley, S.P.; Esker, P.D.; Lauer, J.G.; Ané, J.M. Crop rotation and management effect on Fusarium spp. populations. Crop Sci. 2015, 55, 365-376. [CrossRef]

60. Bezdicek, D.F.; Granatstein, D. Crop rotation efficiencies and biological diversity in farming systems. Am. J. Altern. Agric. 1989, 4, 111-119. [CrossRef]

61. Arpaci, B.B.; Akinci, İ.E.; Kisakurek, M.N.; Gozcu, D.; Yarali, F.; Candemir, S. Effect of crop rotation on yield and weed density for organic red pepper cultivation in Kahramanmaras. Agric. Sci. Res. J. 2016, 6, 63-70.

62. Beillouin, D.; Ben-Ari, T.; Malezieux, E.; Seufert, V.; Makowski, D. Positive but variable effects of crop diversification on biodiversity and ecosystem services. Glob. Change Biol. 2021, 27, 4697-4710. [CrossRef]

63. Shabani, F.; Ahmadi, M.; Kumar, L.; Solhjouy-fard, S.; Tehrany, M.S.; Shabani, F.; Kalantar, B.; Esmaeili, A. Invasive weed species' threats to global biodiversity: Future scenarios of changes in the number of invasive species in a changing climate. Ecol. Indic. 2020, 116, 106436. [CrossRef]

64. Wan, J.; Wang, C. Contribution of environmental factors toward distribution of ten most dangerous weed species globally. App. Ecol. Environ. Res. 2019, 17, 14835-14846. [CrossRef]

65. Murphy, S.D.; Clements, D.R.; Belaoussoff, S.; Kevan, P.G.; Swanton, C.J. Promotion of weed species diversity and reduction of weed seedbanks with conservation tillage and crop rotation. Weed Sci. 2006, 54, 69-77. [CrossRef] 
66. Aktar, M.W.; Sengupta, D.; Chowdhury, A. Impact of pesticides use in agriculture: Their benefits and hazards. Interdiscip. Toxicol. 2009, 2, 1. [CrossRef]

67. Cheng, C.; Pan, J.; Wan, K. Research advances in the effects of rotation on cropland weeds. Chin. Agric. Sci. Bull. 2013, 29, 1-9.

68. Zohry, A.; Ouda, S. Crop rotation defeats pests and weeds. Crop Rotat. 2018, 1, 77-88.

69. Brankov, M.; Simić, M.; Dragičević, V. The influence of maize-winter wheat rotation and pre-emergence herbicides on weeds and maize productivity. Crop Prot. 2021, 143, 105558. [CrossRef]

70. Gao, J.; Xu, M.; Cao, W.; Nie, J.; Dong, C.; Wen, S. Effects of Long-term Rice-Rice-Milk Vetch Rotation for 28 Years to Rice Yield and Weed Species Diversity. Chin. Agric. Sci. Bull. 2010, 17, 155-159.

71. Xie, W.; Huang, J.; Wang, J.; Cui, Q.; Robertson, R.; Chen, K. Climate change impacts on China's agriculture: The responses from market and trade. China Econ. Rev. 2020, 62, 101256. [CrossRef]

72. Lin, E.; Xiong, W.; Ju, H.; Xu, Y.; Li, Y.; Bai, L.; Xie, L. Climate change impacts on crop yield and quality with CO2 fertilization in China. Philos. Trans. R. Soc. B Biol. Sci. 2005, 360, 2149-2154.

73. Degani, E.; Leigh, S.; Barber, H.M.; Jones, H.E.; Lukac, M.; Sutton, P.; Potts, S.G. Crop rotations in a climate change scenario: Short-term effects of crop diversity on resilience and ecosystem service provision under drought. Agric. Ecosyst. Environ. 2019, 285, 106625. [CrossRef]

74. Dokken, D.; Gitay, H.; Suarez, A.; Watson, R.T. Climate Change and Biodiversity; Intergovernmental Panel on Climate Change: Geneva, Switzerland, 2002; pp. 2-51.

75. Torralba, M.; Fagerholm, N.; Burgess, P.J.; Moreno, G.; Plieninger, T. Do European agroforestry systems enhance biodiversity and ecosystem services? A meta-analysis. Agric. Ecosyst. Environ. 2016, 230, 150-161. [CrossRef]

76. Gong, Z.; Lin, P.; Chen, J.; Hu, X. Classical farming systems of China. J. Crop Prod. 2001, 3, 11-21. [CrossRef]

77. Lu, Y. A History of Chinese Science and Technology, 1st ed.; Springer: Berlin, Germany, 2015; pp. 1-624.

78. Baohe, M.; Songlie, Y.; Xiangdong, L.; Jianxin, P.; Shengjun, W.; Fengjuan, W.; Fenglan, L.; Fengqiu, Q.; Yangyong, D.; Changjin, Z.; et al. The Science of Crop Cultivation Assume Gloomy Prospects in China. Chin. Agric. Sci. Bull. 2005, 21, 445-448.

79. Ma, B.L. Crop Rotations: Farming Practices, Monitoring and Environmental Benefits, 1st ed.; Nova Science: New York, NY, USA, 2016; pp. 51-69.

80. Qiu-jie, S. Recovery, Development of Agricultural Production and Act of Government at the Beginning of Tang Dynasty. J. Anhui Agric. Sci. 2009, 35, 9308-9309.

81. Shi, Z. 5 Development and Limitations of Agriculture in the Qing Dynasty. Agric. Dev. Qing China 2017, 1, 153-176.

82. Jowett, A.J. China's foodgrains: Production and performance, 1949-1981. GeoJournal 1985, 10, 373-388. [CrossRef]

83. Liu, L.; Xu, X.; Zhuang, D.; Chen, X.; Li, S. Changes in the potential multiple cropping system in response to climate change in China from 1960-2010. PLoS ONE 2013, 8, e80990. [CrossRef]

84. Yang, Q.; Chen, Z.; Xin, G.; Zeng, L. The historical evolution of Chinese cultivation system and some thoughts on the current land fallow and crop rotation policy. West Forum 2018, 28, 1-8.

85. Food and Agricultural Organization (FAO). Report on the Agro-Ecological zones Project, 1st ed.; FAO: Rome, Italy, 1978.

86. Huang, J.; Ridoutt, B.G.; Thorp, K.R.; Wang, X.; Lan, K.; Liao, J.; Tao, X.; Wu, C.; Huang, J.; Chen, F.; et al. Water-scarcity footprints and water productivities indicate unsustainable wheat production in China. Agric. Water Manag. 2019, 224, 105744. [CrossRef]

87. Zhang, J.; Zhang, C.; Bai, H.; Li, L.; Sun, L.; Liu, D.; Wang, L.; Diao, G. New Development of Climate Change in Northwest China and Its Impact on Arid Environment. J. Arid. Meteorol. 2010, 28, 1-7.

88. Deng, Z.; Zhang, Q.; Pu, J.Y.; Liu, D.X.; Guo, H.; Wang, Q.F.; Zhao, H.; Wang, H.L. The impact of climate warming on crop planting and production in northwestern China. Acta Ecologica Sinica 2008, 28, 3760-3768.

89. Zuber, S.M.; Behnke, G.D.; Nafziger, E.D.; Villamil, M.B. Crop rotation and tillage effects on soil physical and chemical properties in Illinois. Agron. J. 2015, 107, 971-978. [CrossRef]

90. Zhou, S.; Tan, G.; Shen, Y.Y.; Nan, Z.B.; Gao, C.Y.; Li, G.D.; Yang, J. Dynamics of soil water and water use efficiency within Maize-Winter Wheat-Soybean rotation under different tillage treatments in the Longdong Loess Plateau. Pratacult. Sci. 2008, $25,69-76$

91. Zhang, H.; Zhao, X.; Yin, X.G.; Liu, S.L.; Xue, J.F.; Wang, M.; Pu, C.; Lal, R.; Chen, F. Challenges and adaptations of farming to climate change in the North China Plain. Clim. Change 2015, 129, 213-224. [CrossRef]

92. Wang, Y.; Ma, S. Technological options of regional agricultural adaptation to climate change in China. Chin. J. Agrometeorol. 2009, $30,51-56$.

93. Sustainable Agriculture Research and Education. Available online: https://www.sare.org/wp-content/uploads/Smart-WaterUse-on-Your-Farm-or-Ranch.pdf (accessed on 23 November 2021).

94. Qin, X.; Liu, K.; Zhou, L.L.; Zhou, S.L.; Lu, L.Q.; Wang, R.Z. Characteristics of annual water utilization in winter wheat-summer maize rotation system in North China Plain. Scientia Agric. Sinica 2012, 45, 4014-4024.

95. Chen, C.; Qian, C.; Deng, A.; Zhang, W. Progressive and active adaptations of cropping system to climate change in Northeast China. Eur. J. Agron. 2012, 38, 94-103. [CrossRef]

96. Xie, L.; Li, Y.; Lin, M. Response and adaptation to climate change of agriculture and environment in Northeast China. Chin. J. Eco-Agric. 2011, 19, 197-201. [CrossRef]

97. Wang, Z.; Liu, B.; Wang, X.; Gao, X.; Liu, G. Erosion effect on the productivity of black soil in Northeast China. Sci. China Ser. D Earth Sci. 2009, 52, 1005-1021. [CrossRef] 
98. Li, H.; Qiu, J.; Wang, L.; Tang, H.; Li, C.; Van Ranst, E. Modelling impacts of alternative farming management practices on greenhouse gas emissions from a winter wheat-maize rotation system in China. Agric. Ecosyst. Environ. 2010, 135, 24-33. [CrossRef]

99. Xu, Y.; Ding, Y.H.; Zhao, Z.C. Prediction of climate change in middle and lower reaches of the Yangtze River in the 21st century. J. Nat. Disasters 2004, 13, 25-31.

100. Zhu, B.; Yi, L.; Guo, L.; Chen, G.; Hu, Y.; Tang, H.; Xiao, C.; Xiao, X.; Yang, G.; Acharya, S.N.; et al. Performance of two winter cover crops and their impacts on soil properties and two subsequent rice crops in Dongting Lake Plain, Hunan, China. Soil Tillage Res. 2012, 124, 95-101. [CrossRef]

101. Fageria, N.K.; Baligar, V.C.; Bailey, B.A. Role of cover crops in improving soil and row crop productivity. Commun. Soil Sci. Plant Anal. 2005, 36, 2733-2757. [CrossRef]

102. Zhao, Q.; Gao, X.; Ning, X.G.; Wu, D.; Cao, W.D. Effects of spring maize and winter cover crop rotation on accumulation of carbon and nitrogen and soil nutrition and microbe in north China. J. Plant Nutr. Fertil. 2013, 19, 1005-1011.

103. Wang, H.; Yi, X.; Chen, Y.; Wang, Q. Effects and influencing factors of the subsidy policy for crop rotation between grains and beans: Case study of Hailun city and Nenjiang county of Heilongjiang province. Res. Agric. Mod. 2019, 40, 638-645.

104. Taxpayers for Common Sense. Available online: https://www.taxpayer.net/wp-content/uploads/2018/03/Report-Effects-ofFarm-Subsidies-on-Farm.pdf (accessed on 22 January 2021).

105. USDA. Natural Resources Conservation Service. Available online: https://www.nrcs.usda.gov/wps/portal/nrcs/main/ national/programs/financial/eqip/ (accessed on 10 December 2021).

106. Liang, L.; Wang, Y.; Ridoutt, B.G.; Lal, R.; Wang, D.; Wu, W.; Wang, L.; Zhao, G. Agricultural subsidies assessment of cropping system from environmental and economic perspectives in North China based on LCA. Ecol. Indic. 2019, 96, 351-360. [CrossRef]

107. Li, T.; Long, H.; Zhang, Y.; Tu, S.; Ge, D.; Li, Y.; Hu, B. Analysis of the spatial mismatch of grain production and farmland resources in China based on the potential crop rotation system. Land Use Policy 2017, 60, 26-36. [CrossRef]

108. Wu, Y.; Zhang, G. American Co-operative agricultural extension system and its enlightenment for China. J. Shanxi Agric. Univ. (Soc. Sci. Ed.) 2003, 2, 371-374.

109. Lei, C.; Li, T. Restricting factors and countermeasures of crop rotation and fallow. Rural. Econ. Sci.-Technol. 2018, $29,53-54$.

110. Zhu, G.; Li, X.; Shi, Y.; Zhang, Y.; Li, Z. Comparison of crop rotation and land fallow between China and foreign countries and its policy implications. J. China Agric. Resour. Reg. Plan. 2018, 39, 35-41. 